
$\$$ Research Square
Preprints are preliminary reports that have not undergone peer review.
They should not be considered conclusive, used to inform clinical practice, or referenced by the media as validated information.

\title{
What impact have Covid-19 pandemic on number of death occurring at the Emergency Department: A Retrospective Analysis of Mortality in India from January 2019 to May 2021
}

Dr Piyush Kumar ( $\sim$ drpiyush003@gmail.com )

Health Department, Government of Bihar https://orcid.org/0000-0001-9857-478X

\section{Research Article}

Keywords: Emergency department, Death, Covid-19, Pandemic, Health facilities

Posted Date: January 12th, 2022

DOI: https://doi.org/10.21203/rs.3.rs-1245972/v1

License: (a) This work is licensed under a Creative Commons Attribution 4.0 International License. Read Full License 


\section{Abstract}

\section{Background}

Acute treatment in emergency case management is required for survival and stabilization of critical patients, followed by a shifting to the relevant medical department for further care. However, for the seriously ill critical patients, i.e., when the care provided by the Emergency Department (ED) of the hospital is not enough to enable transfer, death may occur while treatment in the emergency department. This aspect of emergency management is often overlooked, and very few researcher and government is really serious regarding who dies in the ED.

\section{Aim and Objective}

The aim of my study was to determine the total Mortality occurring in India from $1^{\text {st }}$ January 2019 to $31^{\text {st }}$ May 2021(limitation here due to data availability is limited from accredited source) of emergency department admissions of public and private health facilities. The objective is to find out if there is increase or decrease in mortality of emergency department admissions during the covid-19 pandemic era by comparing average mortality of ED per month of public, private, rural, urban health facilities before the pandemic from $1^{\text {st }}$ and $2^{\text {nd }}$ year of pandemic i.e. 2020 and 2021 respectively

\section{Methods}

This research study is a cross sectional retrospective analysis of the mortality occurring at the emergency department of public and private, rural, urban hospitals from $1^{\text {st }}$ January 2019 to May $31^{\text {st }} 2021$ with aim to find out impact of covid-19. Electronic patient records from HMIS (health management information system) of MoHFW (ministry of health and family welfare), Government of India is collected, observed, analysed, compared for all patients deaths occurring at Emergency Department (ED) of public and private, rural, urban health facilities $(n=452102)$ during the period January 2019 to May 2021.

\section{Results}

The study results found that largest total number of death occurred in the ED during may 2021 whereas the least number of deaths occurred in February 2019 (limitation is data availability up to May 2021 from accredited sources). During the first year of the pandemic, average mortality per month (Jan2020-Dec2020) in the emergency department (ED) of rural, urban, public and private hospitals in India was 16067per month whereas before the pandemic it was 12542 per month while during second year of pandemic i.e. 2021 the average mortality increased to 21758 per month (up to May 2021).

\section{Discussion}

Recently a new strain omicron has again disrupted the normal life and lockdown and other measures are being implemented by different countries to save lives. The mortality at ED are having various aetiologies, clinical severity at time of admission has a direct correlation with mortality, which requires the necessity of 
advanced triage system. There exists a lack of proper knowledge and advanced directives in the beginning i.e. December 2019 of the covid-19 pandemic era.

\section{Conclusions}

Due to novel disease majority of clinicians have challenging situation as well as Emergency Medicine (EM) teams faced a sudden increase in the number of cases with limited resources. Furthermore, a lack of proper knowledge and directives may have hindered access to proper care, as witnessed in many part of the world and available in various literatures. The authors hope that this study will help global researchers as well as policy makers to promote further research and discussion into preparation methods for such pandemics to reduce patient's risk of death in the ED.

\section{Background}

Acute treatment in emergency case management is required for survival and stabilization of critical patients, followed by a shifting to the relevant medical department for further care. However, for the seriously ill critical patients, i.e., when the care provided by the Emergency Department (ED) of the hospital is not enough to enable transfer, death may occur while treatment in the emergency department. This aspect of emergency management is often overlooked, and very few researcher and government is really serious regarding who dies in the ED. This research study is a retrospective analysis of the mortality occurring at the emergency department of public and private hospitals from 1st January 2019 to May31st 2021 with aim to find out impact of covid-19. The first case of covid-19 was reported from Wuhan in China during December 2019 and a state of acute emergency is still going on around the globe [1].

For better understanding the impact of the SARS-CoV-2 pandemic on hospital healthcare, I have studied mortality occurring in the emergency department (ED) of rural, urban, public and private hospitals in India during this covid-19 pandemic era and compared it with the period before January 2020 when this pandemic has not accounted for a single documented case in India. The World Health Organization (WHO) declared on March 11, 2020, the novel coronavirus (SARS-CoV-2) outbreak a global pandemic. The first documented case in India was found in January 2020 hence up to December 2019 mortality in ED I have considered as prepandemic era deaths [1]. India had reported the first documented death from Covid-19 on 12 March 2020 from the state of Karnataka [2].

Starting from Dec 2019 SARS-CoV-2 caused a global pandemic of disease resulting in substantial excess mortality and major disruption to healthcare. The first year i.e. 2020 COVID-19 cases in India prompted a national lockdown which had also reduced OPD (out patient department) patients of different noncommunicable diseases [3]. Lockdown measures changed during the second year 2021 of pandemic and covid-19 vaccination programme started countrywide in 2021. During this pandemic, healthcare restructuring and modification is going on from local to national levels in anticipation of predicted needs. Reports of reductions in OPD for non-COVID-19 acute illnesses have raised questions that several patients may not have attended hospital for an acute illness. There are several factors influencing hospital admission during the pandemic such as fear of acquiring COVID-19 infection. 
In India, acute hospital care is given to patients reporting directly to the emergency department (ED) of any hospital or if required referred by their primary health centre to higher canters.

\section{Aim And Objective}

The aim of my study was to determine the total Mortality occurring in India from 1st January 2019 to 31 st May 2021 (limitation due to data availability is limited from accredited source) of emergency department admissions of public and private health facilities. The objective is to find out if there is increase or decrease in mortality during the covid-19 pandemic era by comparing average mortality per month before the pandemic from 1st and 2nd year of pandemic i.e. 2020 and 2021 respectively (also called first and second wave which author feels a misnomer as the wave definition and terminology in context of covid-19 is not established and there are also small waves in between as well as different countries have different peak-time of cases and mortality due to covid-19 pandemic).

\section{Methods}

This research study is a cross sectional retrospective analysis of the mortality occurring at the emergency department of public and private hospitals from 1st January 2019 to May31st 2021 with aim to find out impact of covid-19 on average mortality. Website Electronic patient records of HMIS (health management information system) of MoHFW (ministry of health and family welfare), Government of India is collected, observed, analyzed, compared for all patients deaths occurring at Emergency Department (ED) of both public and private health facilities $(n=452102)$ during the period January 2019 to May 2021.

I have extracted data from the health management information system (HMIS) for all ED patients mortality occurring at the Emergency Department of rural, urban, public and private health facilities in India from January 2019 to May 2021 of all ages and gender $(n=452102)$. In next version of this research study data for medical admissions from the HMIS for pre and pandemic era will also be included for better epidemiological analysis and understanding.

\section{Statistical analysis}

The data for mortality occurring at the Emergency Department of rural, urban, public and private health facilities in India from January 2019 to May 2021 were recorded, calculated and analyzed with Microsoft office in this version 2. Stata software will be used in next version if required.

\section{Results}

\section{Impact of Covid-19 pandemic on number of death occurring at the Emergency Department of all health facilities cumulative}

ED mortality increased sharply from August 2020 following the Unlock 2.0: 1 July 2020 - 31 July 2020 (31 days). From March 2021 the ED mortality have seen a tremendous rise following Unlock 10.0: 1 March 2021 - 
31 March 2021 (31 days) see figure-1. The Government of India had declared a nationwide lockdown on 24th march 2020 as listed below and this lockdown has also disrupted many other essential services [4].

- Lockdown Phase 1: 25 March 2020 - 14 April 2020 (21 days)

- Lockdown Phase 2: 15 April 2020 - 3 May 2020 (19 days)

- Lockdown Phase 3: 4 May 2020 - 17 May 2020 (14 days)

- Lockdown Phase 4: 18 May 2020 - 31 May 2020 (14 days)

The lockdown strategy is found effective to control the covid-19 outbreak but there are several limitations to impose lockdown for longtime [5]. Hence the government of India started unlock as follow [6]:

Unlock:

- Unlock down 1.0: 1 June 2020 - 30 June 2020 (30 days)

- Unlock down 2.0: 1 July 2020 - 31 July 2020 (31 days)

- Unlock down 3.0: 1 August 2020 - 31 August 2020 (31 days)

- Unlock down 4.0: 1 September 2020 - 30 September 2020 (30 days)

- Unlock down 5.0: 1 October 2020 - 31 October 2020 (31 days)

- Unlock down 6.0: 1 November 2020 - 30 November 2020 (30 days)

- Unlock 7.0: 1 December 2020 - 31 December 2020 (31 days)

- Unlock down 8.0: 1 January 2021 - 31 January 2021 (31 days)

- Unlock down 9.0: 1 February 2021 - 28 February 2021 (28 days)

- Unlock down 10.0: 1 March 2021 - 31 March 2021 (31 days)

- Unlock down 11.0: 1 April 2021 - 30 April 2021 (30 days)

- Unlock down 12.0: 1 May 2021 - 31 May 2021 (31 days)

- Unlock down 13.0: 1 June 2021 - 30 June 2021 (30 days)

- Unlock down 14.0: 1 July 2021 - 31 July 2021 (31 days)

- Unlock down 15.0: 1 August 2021 - 31 August 2021 (31 days)

- Unlock down 16.0 : 1 September 2021 - 30 September 2021 (30 days)

- Unlock down $17.0: 1$ October 2021 - 31 October 2021 (31 days)

- Unlock down 18.0: 1 November 2021-30 November 2021 (30 days)

- Unlock down 19.0: 1 December 2021-31 December 2021 (31 days)

- Unlock down 20.0: 1 January 2022-31 January 2022 (9 days)

ED mortality have seen a tremendous rise following Unlock 10.0: 1 March 2021 31 March 2021 
The study results found that largest total number of death occurred in the ED during may 2021 whereas the least number of deaths occurred in February 2019 (limitation is data availability up to May 2021 from accredited sources). During the first year of the pandemic, average cumulative mortality per month (Jan2020Dec2020) in the emergency department (ED) of rural, urban, public and private hospitals in India was 16067per month whereas before the pandemic it was 12542 per month while during second year of pandemic i.e. 2021 the average mortality increased to 21758 per month (up to May 2021).

Table-1- Month wise comparison of Mortality at public-private-urban-rural health facilities of India in 2019 (pre-pandemic era) 


\begin{tabular}{|c|c|c|c|c|c|c|c|c|}
\hline & & & & All India & & & & \\
\hline Month & $\begin{array}{l}\text { Item } \\
\text { code } \\
\text { HMIS }\end{array}$ & $\begin{array}{l}\text { Number of } \\
\text { deaths } \\
\text { occurring } \\
\text { at } \\
\text { Emergency } \\
\text { Department }\end{array}$ & Total & $\begin{array}{l}\text { Total } \\
{[(A+B) \text { or }} \\
(C+D)]\end{array}$ & $\begin{array}{l}\text { Public } \\
{[A]}\end{array}$ & $\begin{array}{l}\text { Private } \\
\text { [B] }\end{array}$ & Urban [C] & Rural [D] \\
\hline Jan-19 & 14.7 & $\begin{array}{l}\text { Number of } \\
\text { deaths } \\
\text { occurring } \\
\text { at } \\
\text { Emergency } \\
\text { Department }\end{array}$ & TOTAL & 15011 & 14709 & 302 & 1619 & 13392 \\
\hline Feb-19 & 14.7 & $\begin{array}{l}\text { Number of } \\
\text { deaths } \\
\text { occurring } \\
\text { at } \\
\text { Emergency } \\
\text { Department }\end{array}$ & TOTAL & 9740 & 9442 & 298 & 1513 & 8227 \\
\hline Mar-19 & 14.7 & $\begin{array}{l}\text { Number of } \\
\text { deaths } \\
\text { occurring } \\
\text { at } \\
\text { Emergency } \\
\text { Department }\end{array}$ & TOTAL & 14280 & 13824 & 456 & 1663 & 12617 \\
\hline Apr-19 & 14.7 & $\begin{array}{l}\text { Number of } \\
\text { deaths } \\
\text { occurring } \\
\text { at } \\
\text { Emergency } \\
\text { Department }\end{array}$ & TOTAL & 11833 & 11511 & 322 & 1516 & 10317 \\
\hline May-19 & '14.7' & $\begin{array}{l}\text { Number of } \\
\text { deaths } \\
\text { occurring } \\
\text { at } \\
\text { Emergency } \\
\text { Department }\end{array}$ & TOTAL & 12077 & 11691 & 386 & 1710 & 10367 \\
\hline Jun-19 & '14.7' & $\begin{array}{l}\text { Number of } \\
\text { deaths } \\
\text { occurring } \\
\text { at } \\
\text { Emergency } \\
\text { Department }\end{array}$ & TOTAL & 12308 & 11834 & 474 & 1763 & 10545 \\
\hline Jul-19 & '14.7' & $\begin{array}{l}\text { Number of } \\
\text { deaths } \\
\text { occurring } \\
\text { at } \\
\text { Emergency } \\
\text { Department }\end{array}$ & TOTAL & 12501 & 12063 & 438 & 1700 & 10801 \\
\hline
\end{tabular}




\begin{tabular}{|c|c|c|c|c|c|c|c|c|}
\hline & & & & All India & & & & \\
\hline Aug-19 & '14.7' & $\begin{array}{l}\text { Number of } \\
\text { deaths } \\
\text { occurring } \\
\text { at } \\
\text { Emergency } \\
\text { Department }\end{array}$ & TOTAL & 13085 & 12619 & 466 & 2012 & 11073 \\
\hline Sep-19 & ' 14.7 ' & $\begin{array}{l}\text { Number of } \\
\text { deaths } \\
\text { occurring } \\
\text { at } \\
\text { Emergency } \\
\text { Department }\end{array}$ & TOTAL & 11914 & 11488 & 426 & 1649 & 10265 \\
\hline Oct-19 & '14.7' & $\begin{array}{l}\text { Number of } \\
\text { deaths } \\
\text { occurring } \\
\text { at } \\
\text { Emergency } \\
\text { Department }\end{array}$ & TOTAL & 13972 & 13421 & 551 & 2400 & 11572 \\
\hline Nov-19 & ' 14.7 ' & $\begin{array}{l}\text { Number of } \\
\text { deaths } \\
\text { occurring } \\
\text { at } \\
\text { Emergency } \\
\text { Department }\end{array}$ & TOTAL & 12069 & 11614 & 455 & 1637 & 10432 \\
\hline Dec-19 & ' 14.7 ' & $\begin{array}{l}\text { Number of } \\
\text { deaths } \\
\text { occurring } \\
\text { at } \\
\text { Emergency } \\
\text { Department }\end{array}$ & TOTAL & 11716 & 11320 & 396 & 1631 & 10085 \\
\hline Total & & & & 150506 & 145536 & 4970 & 20813 & 129693 \\
\hline Average & & & & 12542.17 & 12128 & 414.1667 & 1734.417 & 10807.75 \\
\hline
\end{tabular}

Compared to the pre-pandemic era, in the 1st year of pandemic era the total number of deaths occurring at Emergency Department of rural, urban, public and private hospitals increased 1.28 times or 3525 per month average increase is seen see figure 1, Table 1 and 2 . Compared to pre-pandemic era in the second year of pandemic era the number of deaths occurring at Emergency Department increased 1.73 times or 9216 per month average increase is seen see figure 1, Table 1 and 3.

Table-2 - Month wise comparison of Mortality at public-private-urban-rural health facilities of India in 2020 (first year of pandemic era) 


\begin{tabular}{|c|c|c|c|c|c|c|c|c|}
\hline \multicolumn{9}{|c|}{ All India } \\
\hline & & & & $\begin{array}{l}\text { Total } \\
{[(A+B)} \\
\text { or } \\
(C+D)]\end{array}$ & $\begin{array}{l}\text { Public } \\
\text { [A] }\end{array}$ & $\begin{array}{l}\text { Private } \\
\text { [B] }\end{array}$ & Urban [C] & Rural [D] \\
\hline Jan-20 & '14.7' & $\begin{array}{l}\text { Number of } \\
\text { deaths } \\
\text { occurring at } \\
\text { Emergency } \\
\text { Department }\end{array}$ & TOTAL & 14136 & 13696 & 440 & 2330 & 11806 \\
\hline Feb-20 & '14.7' & $\begin{array}{l}\text { Number of } \\
\text { deaths } \\
\text { occurring at } \\
\text { Emergency } \\
\text { Department }\end{array}$ & TOTAL & 12689 & 12225 & 464 & 2616 & 10073 \\
\hline Mar-20 & '14.7' & $\begin{array}{l}\text { Number of } \\
\text { deaths } \\
\text { occurring at } \\
\text { Emergency } \\
\text { Department }\end{array}$ & TOTAL & 10887 & 10471 & 416 & 1463 & 9424 \\
\hline Apr-20 & ' 14.7 & $\begin{array}{l}\text { Number of } \\
\text { deaths } \\
\text { occurring at } \\
\text { Emergency } \\
\text { Department }\end{array}$ & TOTAL & 14185 & 13831 & 354 & 4821 & 9364 \\
\hline May-20 & '14.7 & $\begin{array}{l}\text { Number of } \\
\text { deaths } \\
\text { occurring at } \\
\text { Emergency } \\
\text { Department }\end{array}$ & TOTAL & 14201 & 13707 & 494 & 6026 & 8175 \\
\hline Jun-20 & '14.7 & $\begin{array}{l}\text { Number of } \\
\text { deaths } \\
\text { occurring at } \\
\text { Emergency } \\
\text { Department }\end{array}$ & TOTAL & 14782 & 13967 & 815 & 5853 & 8929 \\
\hline Jul-20 & '14.7 & $\begin{array}{l}\text { Number of } \\
\text { deaths } \\
\text { occurring at } \\
\text { Emergency } \\
\text { Department }\end{array}$ & TOTAL & 12354 & 11423 & 931 & 5976 & 6378 \\
\hline Aug-20 & '14.7 & $\begin{array}{l}\text { Number of } \\
\text { deaths } \\
\text { occurring at } \\
\text { Emergency } \\
\text { Department }\end{array}$ & TOTAL & 17005 & 16494 & 511 & 7165 & 9840 \\
\hline Sep-20 & '14.7 & $\begin{array}{l}\text { Number of } \\
\text { deaths } \\
\text { occurring at } \\
\text { Emergency } \\
\text { Department }\end{array}$ & TOTAL & 18056 & 17546 & 510 & 10142 & 7914 \\
\hline
\end{tabular}




\begin{tabular}{|c|c|c|c|c|c|c|c|c|}
\hline \multicolumn{9}{|c|}{ All India } \\
\hline Oct-20 & '14.7 & $\begin{array}{l}\text { Number of } \\
\text { deaths } \\
\text { occurring at } \\
\text { Emergency } \\
\text { Department }\end{array}$ & TOTAL & 25014 & 22275 & 2739 & 13444 & 11570 \\
\hline Nov-20 & '14.7 & $\begin{array}{l}\text { Number of } \\
\text { deaths } \\
\text { occurring at } \\
\text { Emergency } \\
\text { Department }\end{array}$ & TOTAL & 22384 & 19679 & 2705 & 8567 & 13817 \\
\hline Dec-20 & '14.7 & $\begin{array}{l}\text { Number of } \\
\text { deaths } \\
\text { occurring at } \\
\text { Emergency } \\
\text { Department }\end{array}$ & TOTAL & 17111 & 16486 & 625 & 7303 & 9808 \\
\hline Total & & & & 192804 & 181800 & 11004 & 75706 & 117098 \\
\hline Average & & & & 16067 & 15150 & 917 & 6308.833 & 9758.167 \\
\hline
\end{tabular}

Table-3- Month wise comparison of Mortality at public-private-urban-rural health facilities of India in 2021 (second year of pandemic era) 


\begin{tabular}{|c|c|c|c|c|c|c|c|c|}
\hline & & & & \multicolumn{5}{|l|}{ All India } \\
\hline & & & & $\begin{array}{l}\text { Total } \\
{[(A+B) \text { or }} \\
(C+D)]\end{array}$ & $\begin{array}{l}\text { Public } \\
\text { [A] }\end{array}$ & $\begin{array}{l}\text { Private } \\
\text { [B] }\end{array}$ & $\begin{array}{l}\text { Urban } \\
\text { [C] }\end{array}$ & $\begin{array}{l}\text { Rural } \\
\text { [D] }\end{array}$ \\
\hline Jan-21 & ' 14.7 & $\begin{array}{l}\text { Number of deaths } \\
\text { occurring at } \\
\text { Emergency } \\
\text { Department }\end{array}$ & TOTAL & 18089 & 15013 & 3076 & 8302 & 9787 \\
\hline Feb-21 & '14.7 & $\begin{array}{l}\text { Number of deaths } \\
\text { occurring at } \\
\text { Emergency } \\
\text { Department }\end{array}$ & TOTAL & 18261 & 16905 & 1356 & 10683 & 7578 \\
\hline Mar-21 & '14.7 & $\begin{array}{l}\text { Number of deaths } \\
\text { occurring at } \\
\text { Emergency } \\
\text { Department }\end{array}$ & TOTAL & 14219 & 13277 & 942 & 6838 & 7381 \\
\hline Apr-21 & '14.7 & $\begin{array}{l}\text { Number of deaths } \\
\text { occurring at } \\
\text { Emergency } \\
\text { Department }\end{array}$ & TOTAL & 21846 & 18957 & 2889 & 10480 & 11366 \\
\hline May-21 & '14.7 & $\begin{array}{l}\text { Number of deaths } \\
\text { occurring at } \\
\text { Emergency } \\
\text { Department }\end{array}$ & TOTAL & 36377 & 32613 & 3764 & 21881 & 14496 \\
\hline Total & & & & 108792 & 96765 & 12027 & 58184 & 50608 \\
\hline Average & & & & 21758.4 & 19353 & 2405.4 & 11636.8 & 10121.6 \\
\hline
\end{tabular}

\section{Impact of Covid-19 pandemic on number of death occurring at the Emergency Department of public health facilities}

The study results found that largest total number of death occurred in the ED of public health facility during may 2021 whereas the least number of deaths occurred in February 2019 (limitation is data availability up to May 2021 from accredited sources). During the first year of the pandemic, average mortality per month (Jan2020-Dec2020) in the emergency department (ED) of public hospitals in India was 15150 per month whereas before the pandemic it was 12128 per month while during second year of pandemic i.e. 2021 the average mortality increased to 19353 per month (up to May 2021).

Compared to pre-pandemic era in the first year of pandemic era the total number of deaths occurring at Emergency Department of public health facility increased 1.24 times or 3022 per month average increase is seen see figure 2, Table 1 and 2. Compared to pre-pandemic era in the second year of pandemic era the number of deaths occurring at Emergency Department of public health facility increased 1.59 times or 7225 per month average increase is seen see figure-2, Table 1 and 3. 


\section{Impact of Covid-19 pandemic on number of death occurring at the Emergency Department of private health facilities}

The study results found that largest total number of death occurred in the ED of private health facility during may 2021 whereas the least number of deaths occurred in February 2019 (limitation is data availability from accredited sources). During the first year of the pandemic, average mortality per month (Jan2020-Dec2020) in the emergency department (ED) of private hospitals in India was 917 per month whereas before the pandemic it was 414 per month while during second year of pandemic i.e. 2021 the average mortality increased to 2405 per month (up to May 2021).

Compared to pre-pandemic era in the first year of pandemic era the total number of deaths occurring at Emergency Department of private health facility increased 2.21 times or 503 per month average increase is seen see figure 3, Table 1 and 2. Compared to pre-pandemic era in the second year of pandemic era the number of deaths occurring at Emergency Department of private health facility increased 5.80 times or 1991 per month average increase is seen see figure 3,Table 1 and 3.

\section{Impact of Covid-19 pandemic on number of death occurring at the Emergency Department of urban health facilities}

The study results found that largest total number of death occurred in the ED of urban health facility during may 2021 whereas the least number of deaths occurred in March 2020 (limitation is data availability up to may 2021 from accredited sources). During the first year of the pandemic, average mortality per month (Jan2020-Dec2020) in the emergency department (ED) of urban hospitals in India was 6308 per month whereas before the pandemic it was 1734 per month while during second year of pandemic i.e. 2021 the average mortality increased to 11636.8 per month (up to May 2021).

Compared to pre-pandemic era in the first year of pandemic era the average total number of deaths occurring at Emergency Department of urban health facility increased 3.64 times or 4574 per month average increase is seen see figure 4, Table 1 and 2. Compared to pre-pandemic era in the second year of pandemic era the number of deaths occurring at Emergency Department of urban health facility increased 6.71 times or 9902 per month average increase is seen see figure 4,Table 1 and 3.

\section{Impact of Covid-19 pandemic on number of death occurring at the Emergency Department of rural health facilities}

The study results found that largest total number of death occurred in the ED of rural health facility during may 2021 whereas the least number of deaths occurred in July 2020 (limitation is data availability up to may 2021 from accredited sources). During the first year of the pandemic, average mortality per month (Jan2020Dec2020) in the emergency department (ED) of rural hospitals in India was 9758 per month whereas before the pandemic it was 10807 per month while during second year of pandemic i.e. 2021 the average mortality reduced to 10121 per month (up to May 2021). 
Compared to pre-pandemic era in the first year of pandemic era the average total number of deaths occurring at Emergency Department of rural health facility reduced by 1.12 times or 1049 per month average decrease is seen see figure 5, Table 1 and 2. Compared to pre-pandemic era in the second year of pandemic era the number of deaths occurring at Emergency Department of rural health facility reduced by 1.07 times or 686 per month average decrease is seen see figure 5,Table 1 and 3.

Here it is remarkable to note that compared to pre-pandemic era in the first year of pandemic era the average total number of deaths occurring at Emergency Department of rural health facility reduced by 1.12 times or 1049 per month average decrease is seen as well as compared to pre-pandemic era in the second year of pandemic era the number of deaths occurring at Emergency Department of rural health facility reduced by 1.07 times or 686 per month average decrease is seen, whereas the urban facilities of healthcare has reported an increase in mortality during covid-19 pandemic years. This may be due to shifting or referral of critical patients to urban higher centers. Still in India it's very unfortunate that urban population is still devoid of higher tertiary centers.

The study results found that largest total number of death occurred in the ED of public health facility during may 2021 whereas the least number of deaths occurred in February 2019 (limitation is data availability from accredited sources). During the first year of the pandemic, average mortality per month (Jan2020-Dec2020) in the emergency department (ED) of public hospitals in India was 15150 per month whereas before the pandemic it was 12128 per month while during second year of pandemic i.e. 2021 the average mortality increased to 19353 per month (up to May 2021).

Compared to pre-pandemic era in the first year of pandemic era the total number of deaths occurring at Emergency Department of public health facility increased 1.24 times or 3022 per month average increase is seen see Table 1 and 2. Compared to pre-pandemic era in the second year of pandemic era the number of deaths occurring at Emergency Department of public health facility increased 1.59 times or 7225 per month average increase is seen see Table 1 and 3.

\section{Discussion}

Recently a new strain omicron has again disrupted the normal life and lockdown and other measures are being implemented by different countries to save lives. The mortality at ED are having various etiologies, clinical severity at time of admission has a direct correlation with mortality, which requires the necessity of advanced triage system. There exists a lack of proper knowledge and advanced directives in the beginning i.e. December 2019 of the covid-19 pandemic era. Of all the facilities only rural facilities reported reduced mortality during covid-19 pandemic era. This may be due to shifting or referral of critical patients to urban higher centers. Still in India it's very unfortunate that urban population is still devoid of higher tertiary centers.

\section{Study Strengths And Limitations}

This is the first article of its kind in the literature, to my knowledge, that has studied, investigated the impact of covid-19 on the number of death occurring at the Emergency Department of rural, urban, public, private health facilities from COVID-19/SARS-CoV-2 pandemic in 36 states and union territories of India. One of the 
most peculiar strength is that the research study data were gathered from reliable accredited sources of Government Health Department. I have analyzed the impact of covid-19 on the number of death occurring at the Emergency Department starting from beginning of pandemic. This is exceptional and totally new idea to determine the ED mortality trends during a pandemic. A limitation is that author has not calculated some epidemiological indicators taking into account the health facility population coverage of the different zones. Another limitation is availability of more data from accredited sources. This limitation will be tried to remove in next version with more data and more epidemiological correlations. The comparison between different health facilities will be added in next version.

\section{Conclusions}

Due to novel disease majority of clinicians have challenging situation as well as Emergency Medicine (EM) teams faced a sudden increase in the number of cases with limited resources. Furthermore, a lack of proper knowledge and directives may have hindered access to proper care, as witnessed in many part of the world and available in various literatures. The authors hope that this study will help global researchers as well as policy makers to promote further research and discussion into preparation methods for such pandemics to reduce patient's risk of death in the ED. Less ED mortality in the first year of the pandemic have given opportunities for reducing ED mortality in the future, but due to delayed or missed care and certainly management failure we have seen rise in mortality during second year of pandemic up to the study period observation. Of course there is limitation to this finding. This research study have identified major changes in ED mortality during the pandemic era and highlight the profound impact of a pandemic on emergency care, even for non-pandemic illness. The author is hopeful that this research study will form a foundation for policy makers for planning to minimize the impact in the future. This research is very broad and to reduce the length of article a short description of facts is presented in this version. More information and advanced analysis will be presented in next version by the author.

\section{Abbreviations}

Emergency Department (ED)

HMIS (health management information system)

MoHFW (ministry of health and family welfare)

\section{Declarations}

\section{Availability of data and materials}

Web based Electronic patient records of HMIS (health management information system) of MoHFW (ministry of health and family welfare), Government of India

-This version of paper has not been previously published and is not currently under consideration by another journal. The document is Microsoft word with English (United States) language \& 4740 words Total. 
- Ethics approval and consent to participate: Not applicable. This study has not involved any human or animals in real or for experiments. The data on the COVID-19 pandemic were taken from the Health Department available as electronic patient records from HMIS (health management information system) of MoHFW (ministry of health and family welfare), Government of India.

-Consent for publication: The author provides consent for publication to anyone for increasing and sharing knowledge to people who need it.

-Availability of data and materials: Electronic patient records from HMIS (health management information system) of MoHFW (ministry of health and family welfare), Government of India.

-Conflicts of Interest/ Competing Interest: There are no conflicts / competing of interest

- Funding-Self sponsored. No aid taken from individual or agency etc.

- Authors' contributions: The whole work is solely done by the Author - Dr Piyush Kumar, M.B.B.S., E.M.O.C., P.G.D.P.H.M., -Senior General Medical Officer- Bihar Health Services- Health Department- Government of Bihar, India.

- Acknowledgements-I am thankful to Advocate Anupama my wife and daughters Aathmika-Atheeva for cooperation.

- Author information: The author is currently working as Senior General Medical Officer for the government of Bihar.

-Financial Support \& sponsorship: Nil

-Author contact information

Department of Health, Government of Bihar,

MOBILE - +919955301119/+917677833752,

Email drpiyush003@gmail.com

\section{References}

1. Kumar, Piyush and Kumar, Piyush, What Are the Factors Responsible for Increase in SARS-CoV-2/COVID19 Pandemic Related Cases and Death in India in 2021? How Does Environmental, Host \& Agent Factors of Epidemiological Triad Do Influence \& Can Be Utilised to Manage Ongoing Pandemic Cases and Deaths? (April 25, 2021). Available at SSRN: https://ssrn.com/abstract=3833788 or http://dx.doi.org/10.2139/ssrn.3833788

2. https://www.thehindu.com/sci-tech/health/indias-first-covid-19-death-confirmed-in-karnataka-totalnumber-of-cases-cross-70/article31053153.ece - India's first COVID-19 death confirmed in KarnatakaThe Hindu 
3. Kumar, Piyush and Kumar, Piyush, What Impact Have SARS-CoV-2/COVID-19 Pandemic Induced Lockdown on the Number of OPD Patients of Diabetes, Hypertension, Stroke (CVA), Acute Heart Disease, Mental Illness, Epilepsy, Ophthalmic, Dental and Oncology in India During the Lockdown Months (AprilMay-2020)-Observational Research Analysis?. Available at SSRN: https://ssrn.com/abstract $=3884940$ or http://dx.doi.org/10.2139/ssrn.3884940

4. Kumar, Piyush and Kumar, Piyush and Farooqui, Habib Hasan, What is the Impact of Covid-19 Pandemic on the RCH (Reproductive and Child Health) Programme in Rajasthan, Because of Nationwide Lockdown (April 2020 to June 2020)?. Available at SSRN: https://ssrn.com/abstract=3914646 or http://dx.doi.org/10.2139/ssrn.3914646

5. Kumar, Piyush and Kumar, Piyush, What Impact Has Lockdown on SARS-CoV-2/COVID-19 Incidence, Prevalence and Mortality During Second Wave of Pandemic in 2021: Observational Analysis of Bihar (6/20/2021). Available at SSRN: https://ssrn.com/abstract=3871321 or http://dx.doi.org/10.2139/ssrn.3871321

6. Ministry of Home Affairs, Government of India, visit- https://www.mohfw.gov.in/pdf/Annexure_MHA.pdf

\section{Figures}

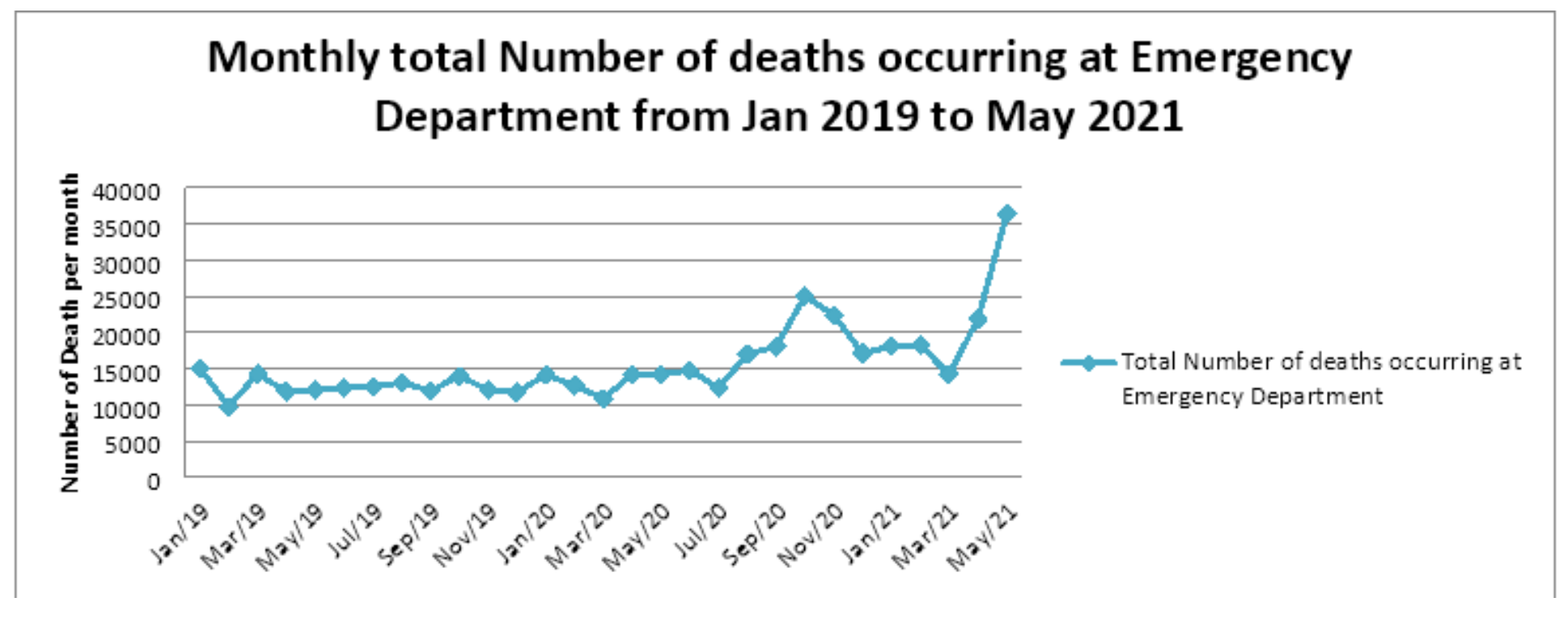

Figure 1

Monthly cumulative death comparison graph at ED of all health facilities 


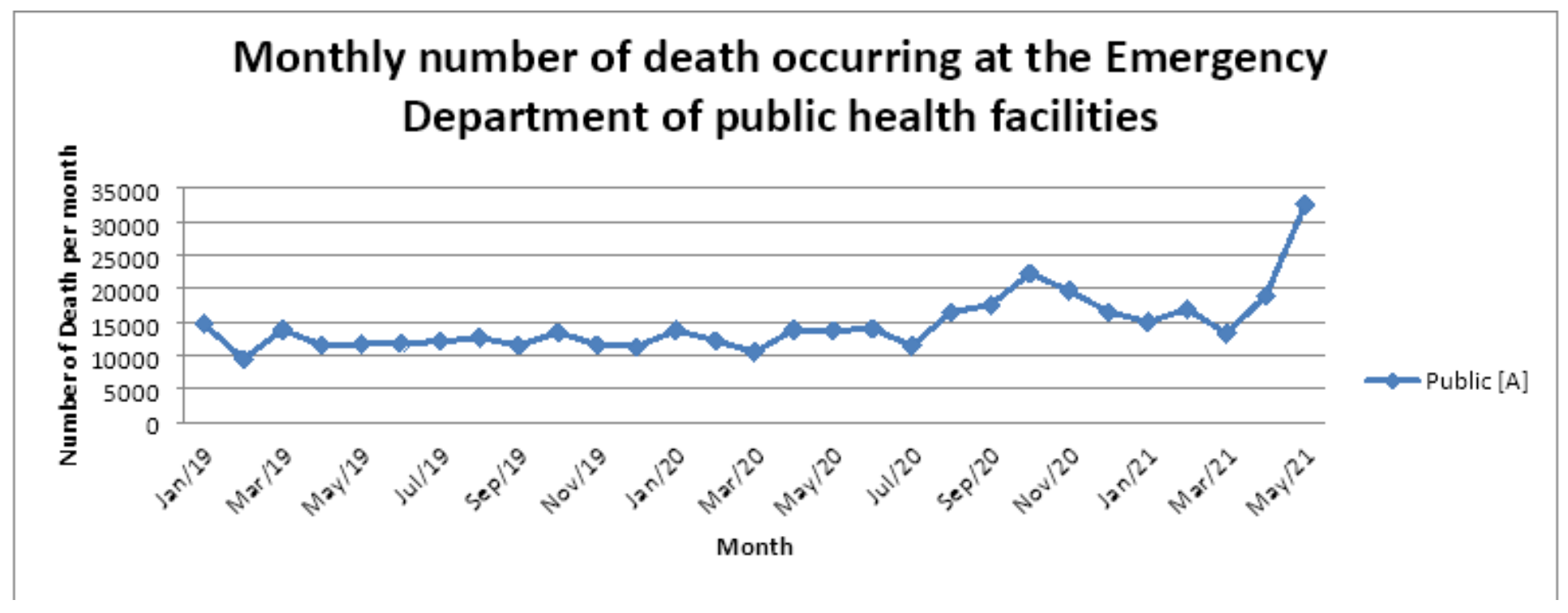

Figure 2

Monthly death comparison graph at ED of public health facilities in India

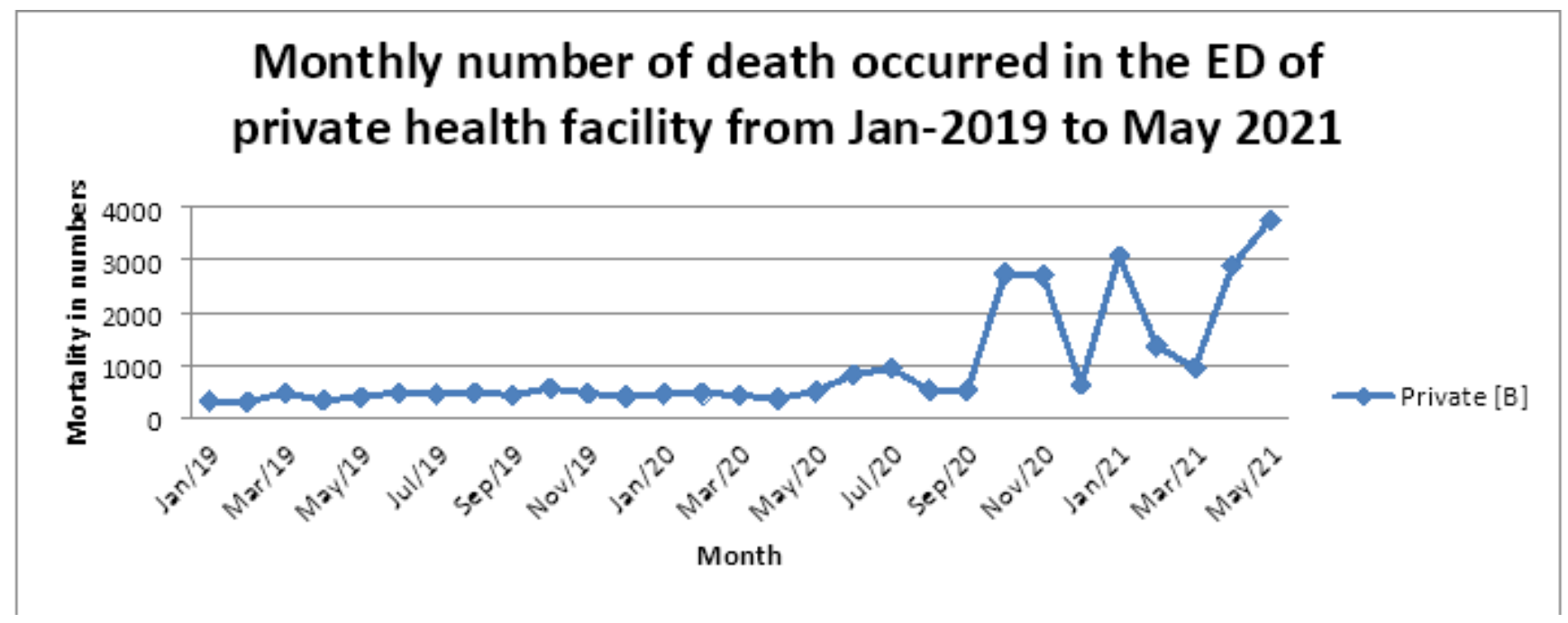

Figure 3

Month wise death comparison graph at ED of private health facilities in India 


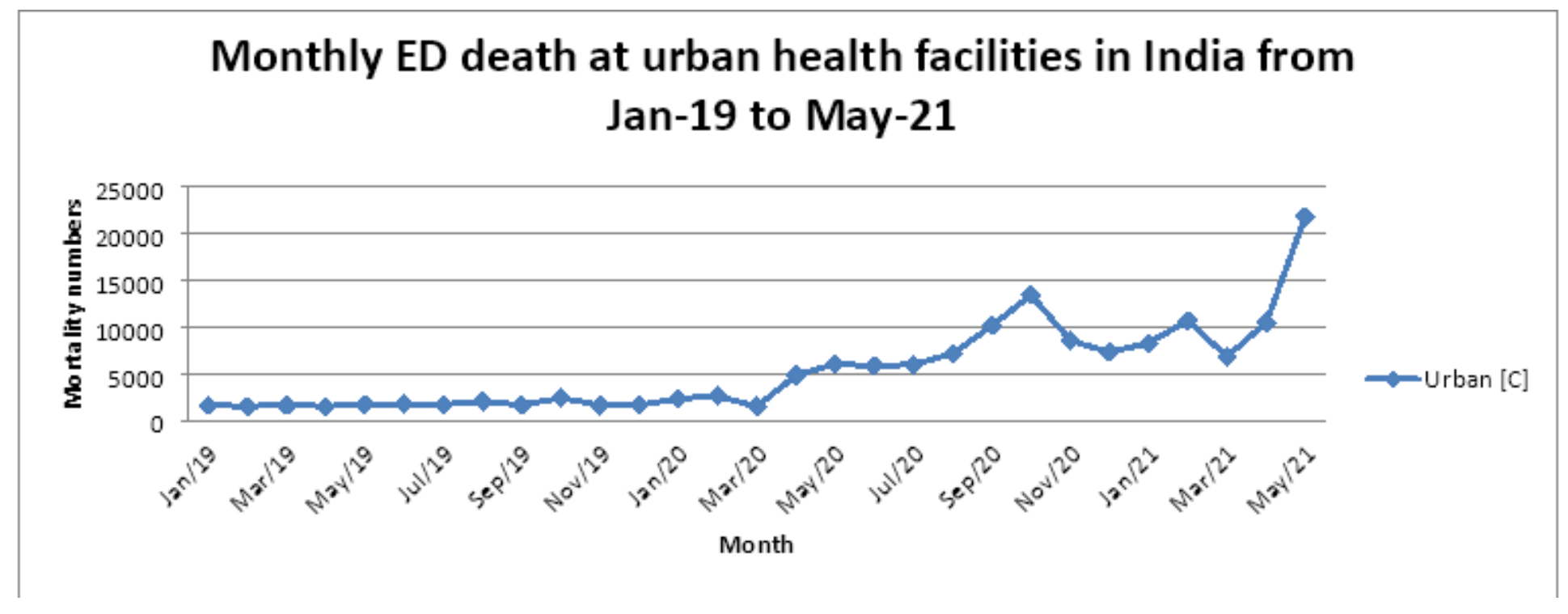

Figure 4

Month wise death comparison graph at ED of urban health facilities in India

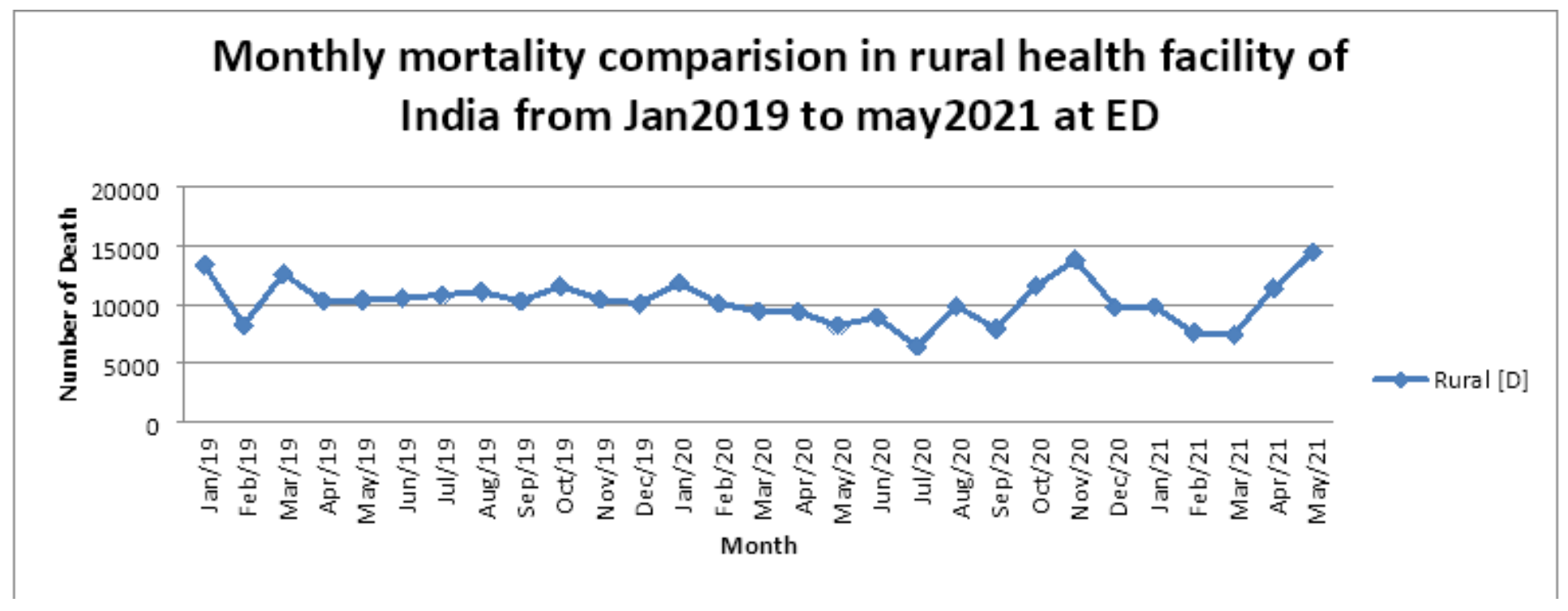

Figure 5

Monthly death comparison graph at ED of rural health facilities in India 